\title{
JIMUSEUMED
}

Çeviri

Translation

\section{Müzelerden İstifâde}

\author{
Kadri (Mahmut Sadık)
}

\author{
(Çeviren: Ece S. TANYELI')
}

\section{Öz}

Kadri [Mahmut Sadık] 1864-1930. İstanbul'da doğmuştur. Mekteb-i Sultanî'de orta öğrenimini, Mekteb-i Mülkiye'de yükseköğrenimi tamamlamış olup, tarım tahsilini gerçekleştirebilmesi maksadıyla Almanya'ya gönderilmiştir. Bir sene boyunca Berlin'de ikâmet ettikten sonra Türkiye'ye dönen Sadık, bir süre devlet memuriyetinde bulunmuş, ardından gazeteciliğe başlayarak Cerîde-i Havâdis, Târîk, Sabah, Saadet, İkdâm, Tercümân-1 Hakîkât gazeteleri ile Servet-i Fünûn dergisinde uzun yıllar mesâi yapmıştır. Balkan Harbinde Sabah gazetesi muhabiri olarak Viyana'da bulunan Sadık, Anadolu-Bağdat Demiryolu İdaresi Neşriyât Amirliği görevini ifâ etmiş ve "Demiryolları" ile "Uyanış - Servet-i Fünûn" dergilerinin mesul yazı işleri müdürlüklerini yürütmüştür. Eğitmenlik görevinde de bulunan Sadık, Türkçe, Fransızca hesap, tarih, iktisâdî coğrafya, usûl-i mâliye öğretmenliği de yapmıştır. İkinci Meşrûtiyet'ten sonra Yeni Gazete'de fıkra ve siyasi mizah yazıları yazan Sadık, 1917 senesinde Matbuat Cemiyeti Başkanlığına seçilmiştir. Kudüs'te de bir dönem ikâmet eden Sadık, 1903 senesinde ülkesine avdet ederek gazetecilik mesleğini sürdürmüştür. Sadık kaleme aldığı çeviriler ile matbuata büyük katkılar sağlamıştır. Bazı yazılarında "Osman Galip" ve "Kadri" isimlerini kullanan Sadık bu yazısında Kadri ismini kullanmış olup, gazete ve mecmualarda müzelere ilişkin neşr edilen yayınların halkın teveccühünü kazanabilmek için sade ve eğlenceli bir dille kaleme alınması tartışmaları üzerine değerlendirmelerini kaydetmiş; müzeleri ziyâret eden halkın ilgisinin taze kalması için önerilerde bulunmuştur. Mezkûr yazı, Servet-i Fünûn'un 238 No'lu sayısında, 21 Eylül 1311 tarihinde yayımlanmıştır.

Anahtar Kelimeler: Müze, asâr-ı atikâ, servet-i fünûn, Mahmut Sadık Kadri
Tür: Çeviri

Yayın Süreci

Gönderim: 19.12.2021

Kabul: 14.01.2022

Yayınlanma: 27.01.2022

\section{우(1) $(8$}

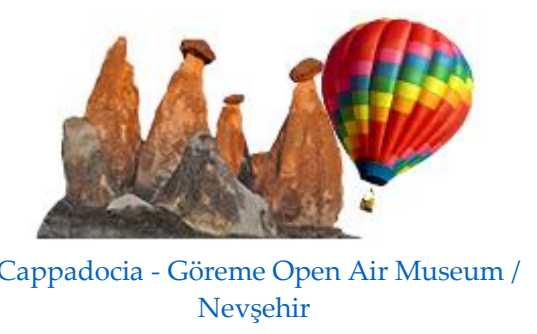

Orijinal Eser Bilgileri

Kadri. (1311). Servet-i Fünûn, 10(238), 55-58.

Önerilen Atıf

Kadri [Mahmut Sadık]. (1311). Müzelerden İstifâde. (Ece S. Tanyeli, Çev.). Uluslararası Müze Ĕ̆itimi Dergisi, 4(1), 70-78. https://doi.org/10.51637/jimuseumed.1038610

"Yıldız Teknik Üniversitesi, İnsan ve Toplum Bilimleri, Tarih Bölümü Yüksek Lisans Öğrencisi, mubeyyizz@gmail.com, https://orcid.org/0000-0002-6888-9999 


\section{Müzelerden İstifâde}

Avrupa ve Amerika'da müzelerin envâı var. Her ne kadar müze deyince anlaşılan asâr-1 atîkanın bir mecmaıdır. Fakat ilm-i medeniyetin her köşesinde bir taraftan açılmakta olan müzeler asâr-ı atîkayı ihtivâ etmek üzere tertip olunmayıp belki lâyenkatı' teceddüt ve terakki etmekte olan asâr-1 muhtelife-i sınâ'îyeyi hâvi olmak üzere müzeler yapılmaktadır. Sergilerle müzelerin şimdiki hâlde bir farkı var ise müzenin daha ciddi daha esaslı olmakla beraber pâyidâr olan tesisât-ı nâfi' adan addedilmelidir.

Müzelerin Avrupa'da terakkiyât-1 mu'ârefe hizmeti fevkalade olup ulûm-u mütenevviadan her birine ait ayrıca bir müze teşkil edilmekte ve bu müze o ilimle mütevaggıl olanlara gayet değerli hizmetler etmektedir. Hayvanât müzesinde en adi ve en küçük böceklerden en cism-i hayvanâta kadar her birinin kendileri kurutulmuş ve dolmuş bir surette bulundurulduğu gibi nesilleri pek çok zaman evvel münkati' olmuş olanlarının bile iskeletleri olsun konuluyor.

Nebâtât müzesi ise her cins otların ve çiçeklerin ve ağaçların birer numunesini ihtivâ eder. Bu müzelere birer de hayvanât ve nebâtât bahçesi mülhak olursa bu iki ilm-i tabiî’den istifâde her cihetle temîn edilmiş olur.

Biz bu makalemizde müzelerin tâ'mîm-i ma'ârif ve halkın tevsî'-i mâ'l'umâtı hususundaki hizmet-i mühimesinden bahsetmek sadedinde değiliz. Bu ciheti musaddak addederiz. Ancak Vaşington müzelerinden birinin müdürü olan Mister Good'un Seyans nâm mecmûâ'-i mühimenin bir makalesinin şâyân-1 ehemmiyet fikralarını zikreylemek istiyoruz.

Bu zâtın meydana koyduğu fikirler gerek yeniden bir müze teşkilinde yâhut mevcut müzelerin hüsn-ü idâresi husûsunda pek fayda-bahş olacağını bazı gazeteler ve risâleler tasdîk ediyorlar.

Müzeden istifâdeyi temîn için dâimâ halkın mizâcına hizmet etmek lâzimeden olup bu da ancak müzede şayan-1 dikkat olan cihetlerin tebdîl ve tahavvülüne sûret-i dâimede gayret etmekle mümkündür. Velev ki asâr-1 atîkayı hâvî olan bir müze olsun. Eğer bunu halk bu sene gördüğ̈ tarzda gelecek sene de görüyorsa ve bu hâl birkaç kere tekrar eder ise o müzeye birkaç kıymetdâr u cüdâ halk tarafından görülmesi ve tedkîk olunması faide-i külliye bahşedecek eserler de vaz' ederlerse halk buna gelip bakmakta müsâmaha eder. “Adam gördüğüm müze!” der de geçer. Halk madem ki biraz da âlâyişe meyyâldir ve bu meyyâlân umûmidir. Niçin bu meyil-i tabî̄’ye hizmet ederek istifâde-i hediyenin temini husûsuna gitmemeli. Nitekim bazı ulûm u fünûn gayet ağır bir dâire dahilinden çıkarılmış ve bu ulûm u fünûna dair ulûmpesendâne ve eğlenceli eserler yazılarak bu suretle fevâidi tâ'm'im olunmuştur.

Velev ki bir şeyde ciddi fâide olsun. Eğer halkın cânını sıkacak ve gayret-i mütemâdiyesini icâb edecek, kendine yorgunluk verecek tarzda olursa bundan kaçanlar çok bulunur. Gazetelerde bile böyledir. Gazetelerin ve risâlelerin en ağır en ciddi ve en mühim mübâhesesini ve makâlât-ı tavîlesini saatler sarf edip düşünce ile okuyanlardan sonra mizâh-âmîz ve kısaca fıkralarını okuyanlar daha çoktur. Bu hâlde bir mesele-i fenniye öğretilmesinde fâide görülür ise yahut ciddi bir mebhas ortaya konulmak istenilirse ciddiyâta eğlence karıştırmanın katiyen aleyhinde bulunanların fikrine muhâlif olarak o mesele yahut o mebhas sade ve eğlenceli yazılarsa okuyanı pek çok bulunur.

Ciddiyât, erbâb-1 ihtisâs için lazımdır. Lakin gazeteler ve risâleler eğer umûm için ise fevkalade ciddi ve yalnız erbâb-ı ihtisâsı müstefîd edecek makalelerden zaten ictinâb ederler. Müzeler erbâb-1 ihtisâs için addedilirse bunca külfetle tertîb ve küşâd olunan ve muhâfazası emrinde küllî masraf ihtiyâr edilen bu tesîsâttan edilecek istifâde pek az kimselere münhasır kalır ve umûm istifâde edemez. Umûmu tetebbû'ât- 
1 fenniyede bulunmaya ve iktisâbât-ı ilmîyeye sây etmeye cebr etmek müşkildir ancak bunlara heves verip kendileri arzu ile tahsîl-i ilm ve kesb-i mâ'lûmât eylemelidirler.

İşte müzeler hakkında beyân-1 efkâr eden Mister Good bu re'ylerde bulunuyor. Mister Good'un makalesini tenkîd edenler efkârından yalnız müzeler değil umûmen istifâde-i mâneviye-i umûmîye çalışan tesisât istifâde edebileceğini teslim etmektedirler.

Bir de usûl ve terbiye tahsîli gayet vâsi' bir fen olup tecârib-i müteâddide ile değiştirilmektedir. Mesela bundan on beş sene evvelki kimya tahsili ile şimdiki kimya tahsili arasında dağlarca fark vardır. Hayvanât ve nebâtât tahsilinde de teshîl eder yolda çareler bulmuşlardır. İşte bu terakkiyâta göre müzelerin tertîbâtı da değiştirilmeli mizâc-1 ahâli de bir an nazardan dur tutulmamalıdır.

Bir müze dâ'imâ bir halkın merakını tahrîk edecek bir nokta bulmalı. Hiç olmazsa elindeki eşyayı dâ'imi surette yeni ve modaya muvaffak bir biçimde istif etmelidir ki halkta merak hâsıl olsun... Meselâ bir asâr1 atîka müzesinde bile bir iki ay asârın kıymet-i tarihiyesi üzerine istif yapılmış ise birkaç ayda kıvâm itibâriyle eserler ayrılmalıdır. Halbûki bir müzeye bir şey konuldu mu, yaftası altına yapıştırıldı mı artık onunla kimse meşgul olmuyor. Ne müzedekiler ne de halk... Her iki taraf intizar ediyor ki yeni bir şey gelsin. Her vakit yeni bir şey bulunmak mümkün değildir. Bilhâssa eski bir şey olur da buna vukûfu olmayanlar bulunabilir. Halbûki kesb-i vukûf etmeği diğer bir takım halkın göreneğine kapılarak ar addeder. Mesela bir müzeye gitmek ister de "vay şimdiye kadar gidip görmedik mi?" demesinler diye çekinir.

Müzelerin sûret-i dâ'imede intizârının tecdîdi bu hicâbı da ortadan kaldırır. Müzeler değil büyük gazinolar, tiyatrolar bile bu kaideye rağbet ederler. Her akşam bir oyun oynayan tiyatro çabuk müşterisini kaybeder. Değil her akşam bir oyun, eski oyunları çokça tekrar edenler de kazanç çok bulamaz. Çoktan beri yeni bir oyun oynamadı diye halk tiyatro idaresini zemm u takbîh eder. Gazinolarda da bir iki çalgı takımı getirmek haylice müşteri celbine vesile oluyor.

Gazino, tiyatro gibi zevk-u safâ mahali addedilen müessesâtın müdürleri halkın mizâcına hizmet etmek dakîkasını fevkâlâde bilirler. Gazeteciler de buna vakıftır. Bir gazete yâhut bir risâle doğrudan doğruya menafi-i umûmiyeye hâdım addedilir. Lakin gazeteci dâ'im'a yeni bir şey bulmaya çalışır. Halkın merakını tahrîk edecek bir nokta ihtirâ' etmek gazeteci için büyük bir şeydir. Hem de risâleler gazeteler eğer makâlât1 mühime ve ciddiye ile millî olarak neşr edilirse ne kadar müdekkikâne mürettep olsa yine müşteri bulamaz. Ziyân eder. Devam edemez. Bunun için hercai mübâhese, eğlenceyi fıkralara lüzûm vardır. Umûmun, istifâde-i mâ'neviyesine hizmet husûsunda müzeler de bu kâideden hariç tutulmaz.

Nasıl bir tabîb-i hâzık "mutlak sûrette filân illete ilaç bu ilaçtır" diye ısrar edip gitmez. Ve bünyeyi ve mizâcı gözeterek hastasına ilaç verir. Bunun gibi asâr- ciddiye-i fenniyenin tâ'mîmini derûhte eden de gayet ağır ibârelerle yazı yazmaktan çekinmez. Yine böyle müzelerde bu gibi ciddi tesîsât, nümâyiş ve âlâyişle tevfîk olunamaz diye ısrar göstermeyip hüsn-ü tabî'atına ve ahlâk-ı millîyeye muvaffâk câlib-i merâk bir tarzda tertip olunmalı. Ufak tefek eğlencelerle halk müzelere celb edilmeli ki bunların istifâde-i mâneviyesi de tâm'im ve temîn edilmiş olsun...

Kadri.

İstanbul: Servet-i Fünûn, 1311 (1895)

Cilt: 10, Say1: 238, Sayfa: 55-58.

Ahmed İhsan ve Şürekâsı Matbaacılık Osmanlı Şirketi / İstanbul 


\section{KAYNAKÇA}

Kadri. (1311). Servet-i Fünûn, 10(238), ss. 55-58. 

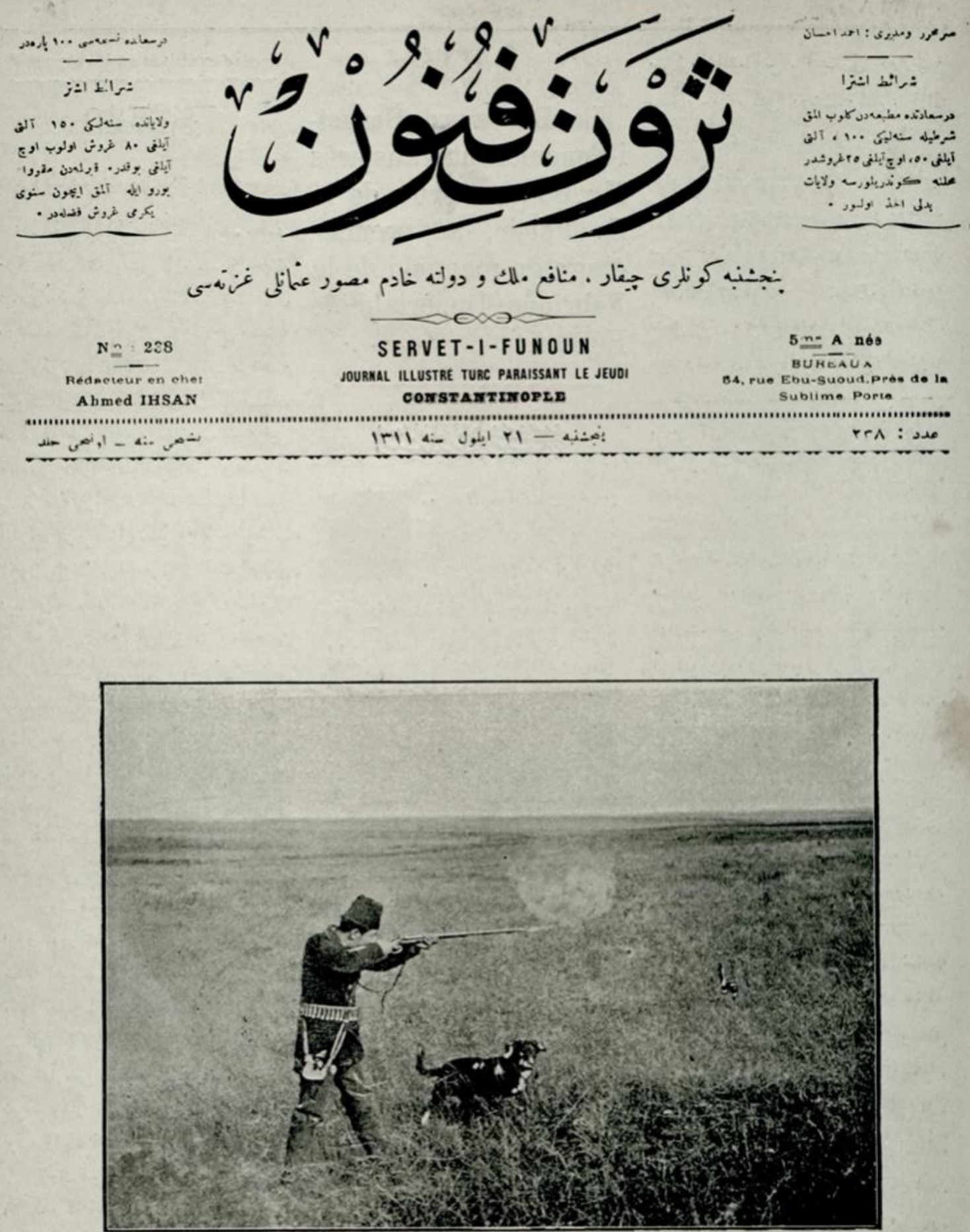

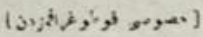

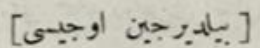

La chasse aux caill es pres de san-Stefano 


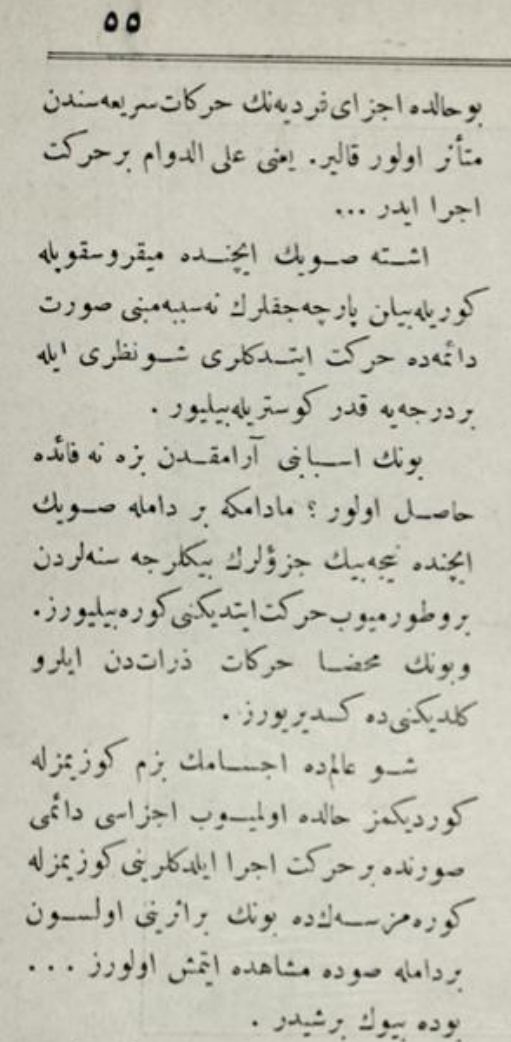

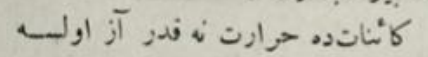

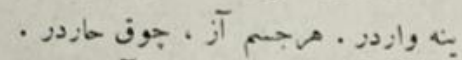

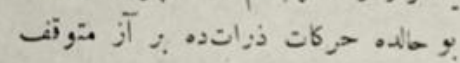

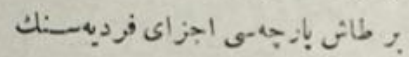

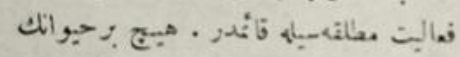

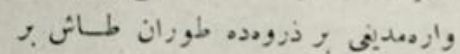

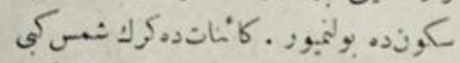

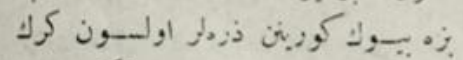

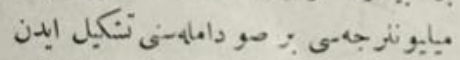

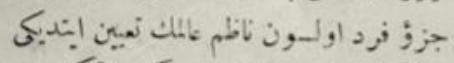

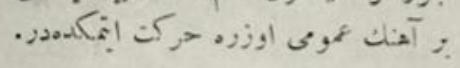

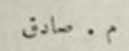

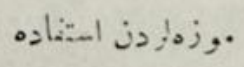

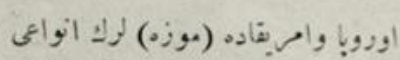
واز. هرنه قدر (موزم) دينجه اكلاثيلان

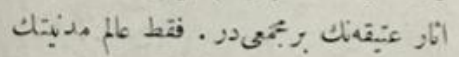

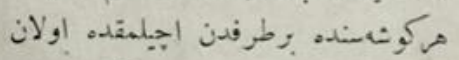

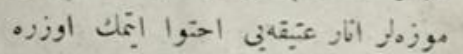

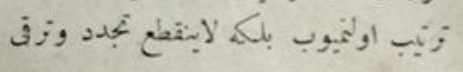

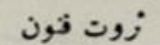

نومת

$\therefore$

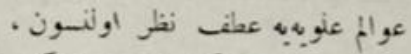

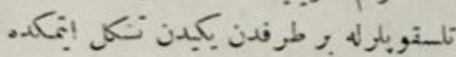

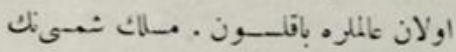

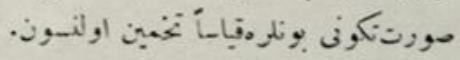

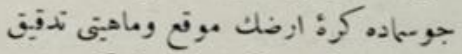

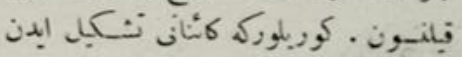

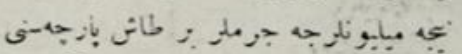

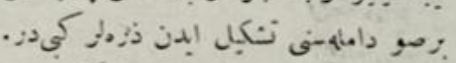

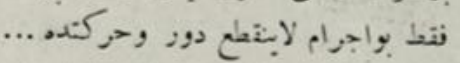

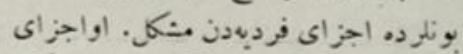

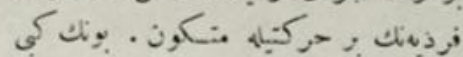

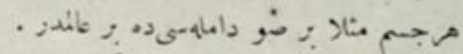

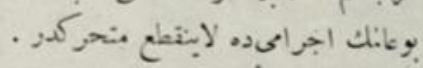

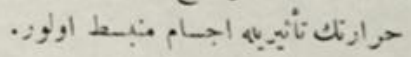

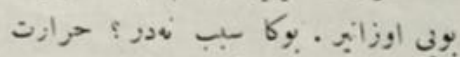

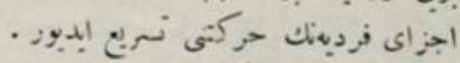

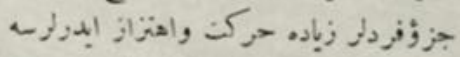

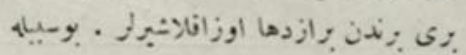

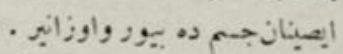

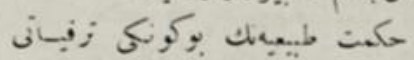

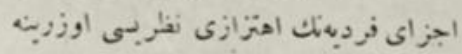

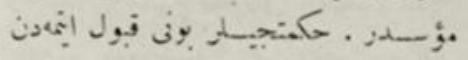

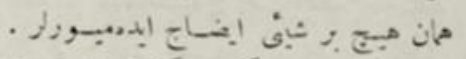

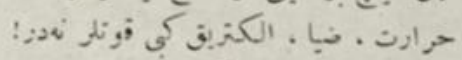

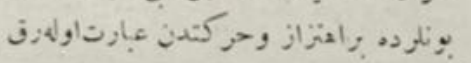
كوريايبون -

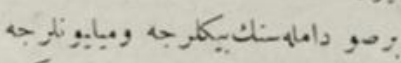

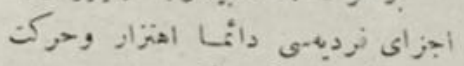

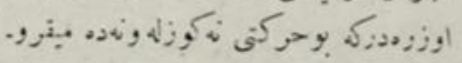

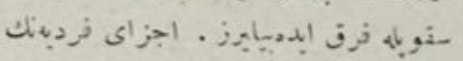

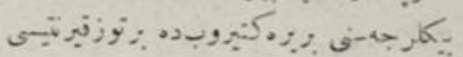

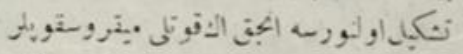

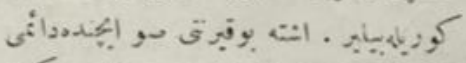

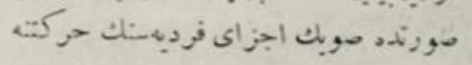

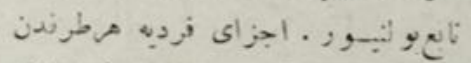

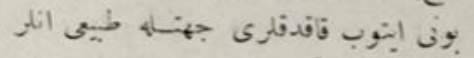

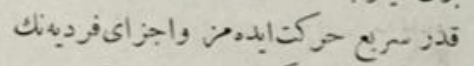

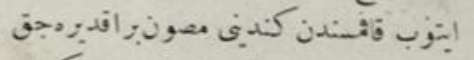

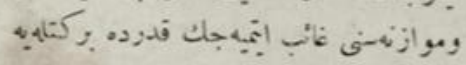

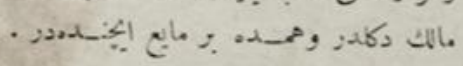

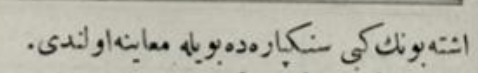

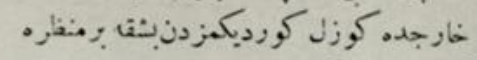

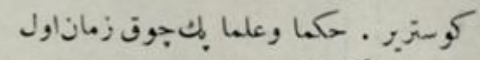

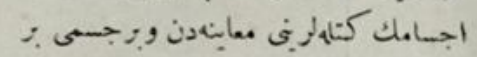

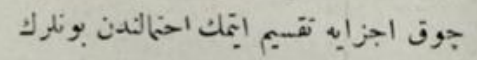

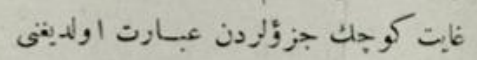

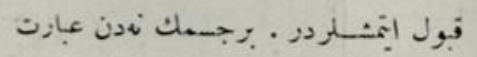
اولديفى اكلامق ايجون بالفعل بونى اجزاء

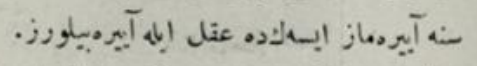

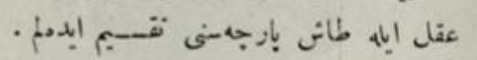

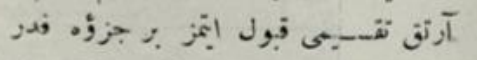

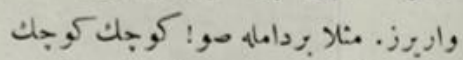

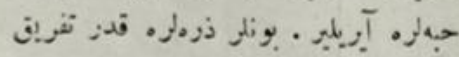

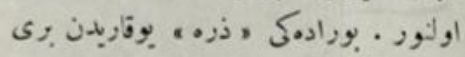

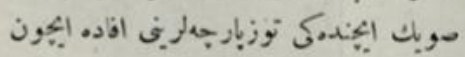
قولماندينمز وعوامك كونش اوريجه هواده

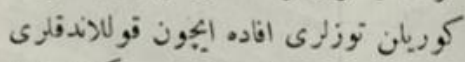

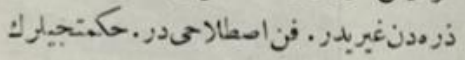

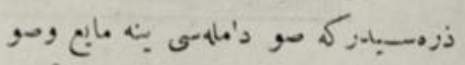

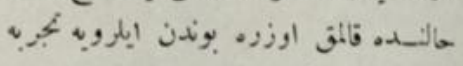

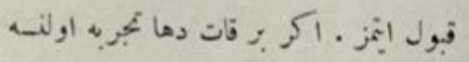

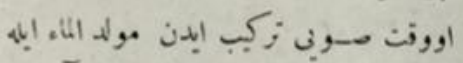

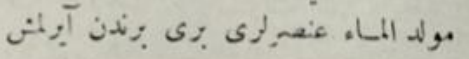

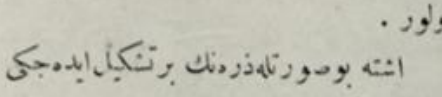

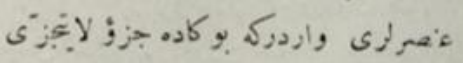

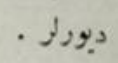

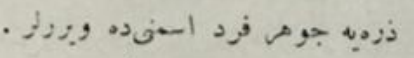

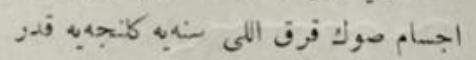

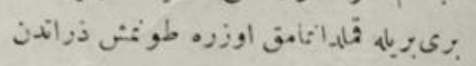

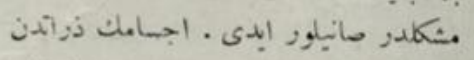

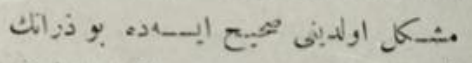

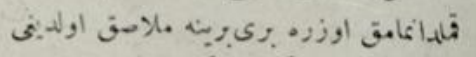

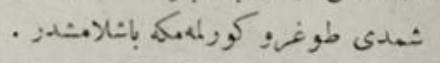

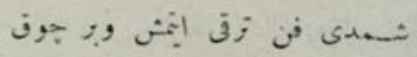

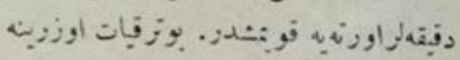

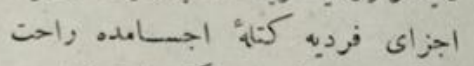

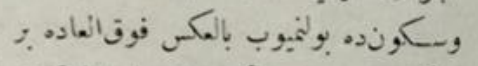

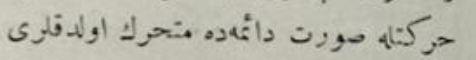
ظن وقبول ابـلثدر . 


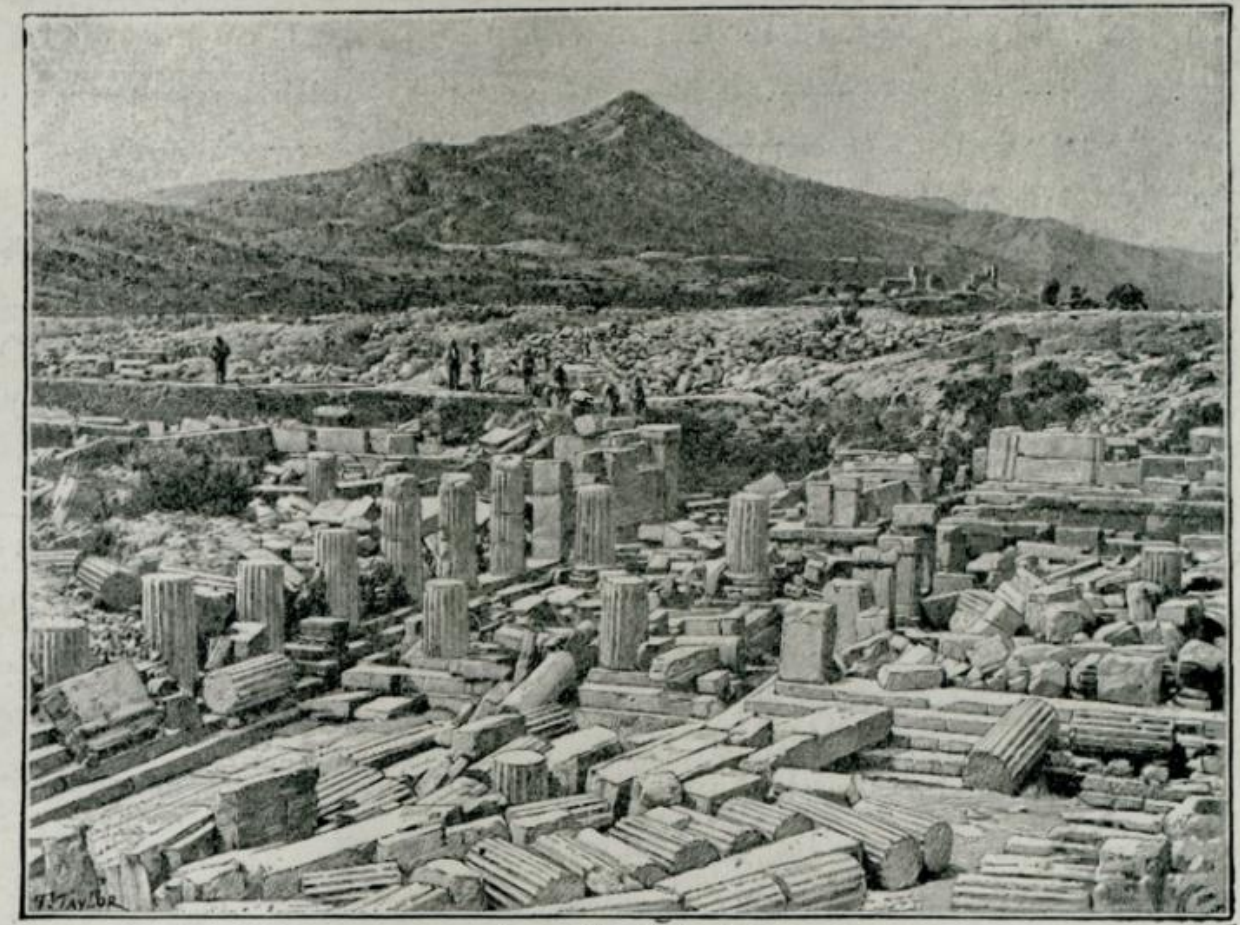

$$
\text { [ [es ruines de Magnesio }
$$

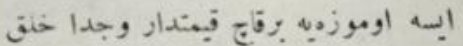

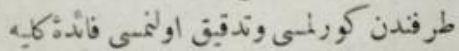

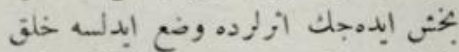

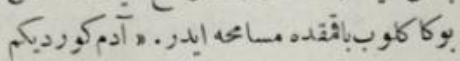

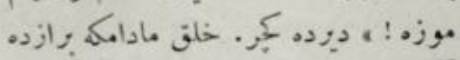

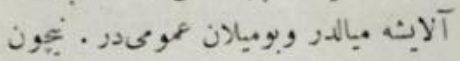

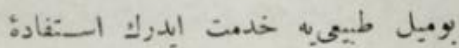

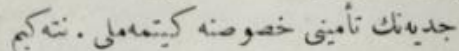

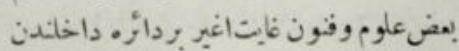

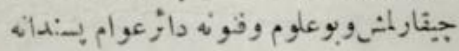

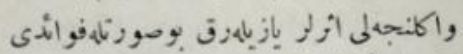
.

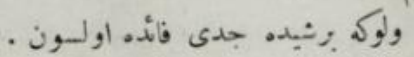

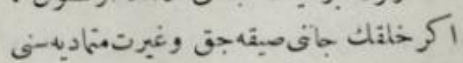

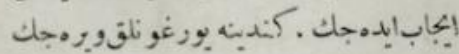

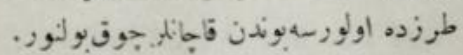

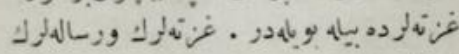

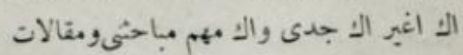

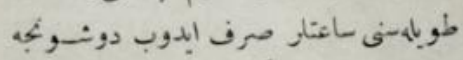

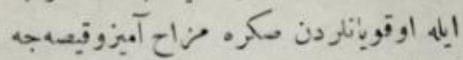

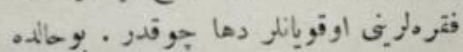

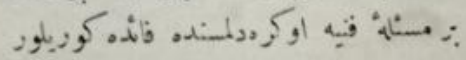

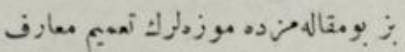

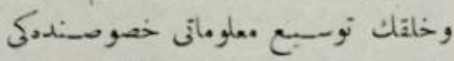

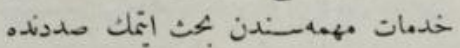

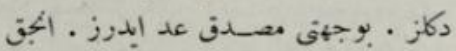

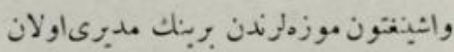

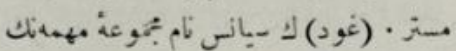

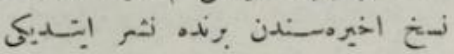

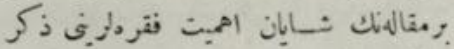

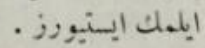

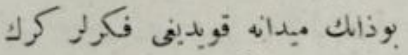

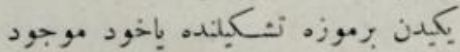

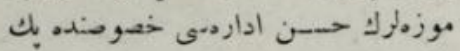

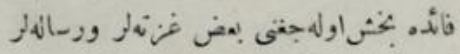

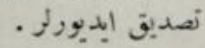

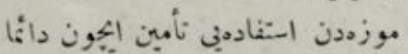

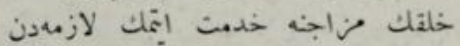
اولوب بوده الحقبموزدده نايان دقتاولان

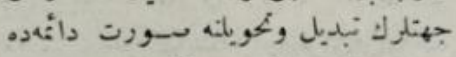

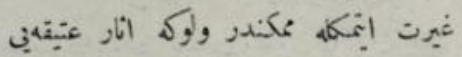

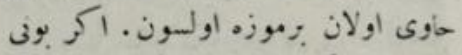

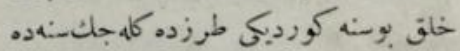

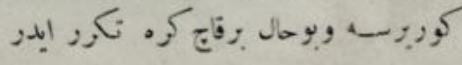

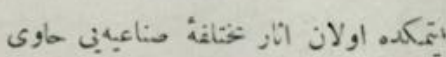

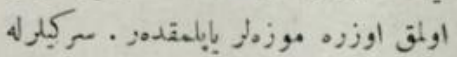

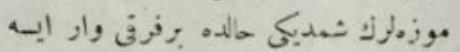

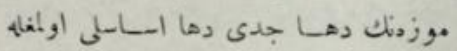

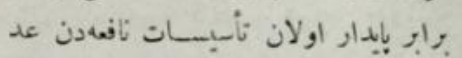
.

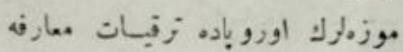

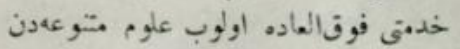

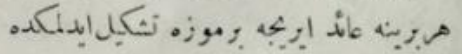

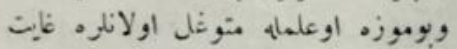

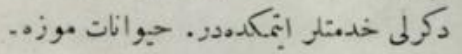

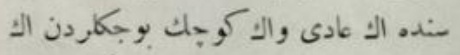

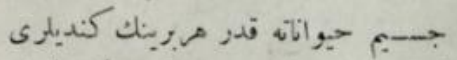

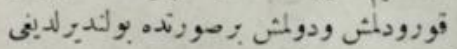

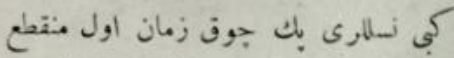

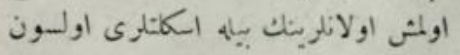

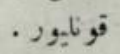

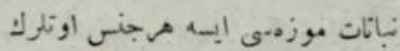

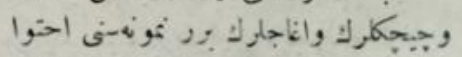

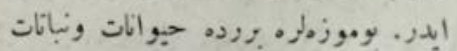

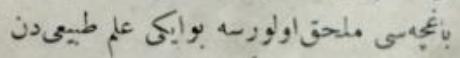

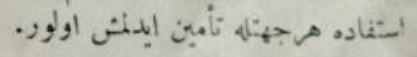




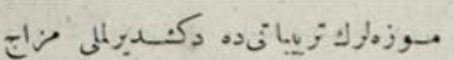

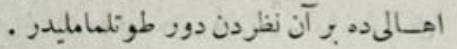

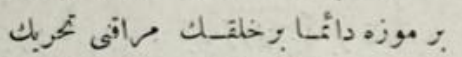

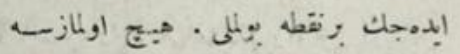

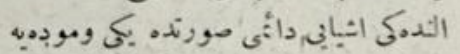

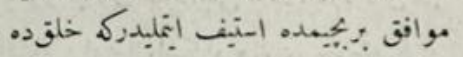

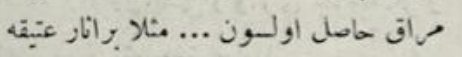

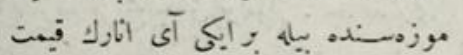

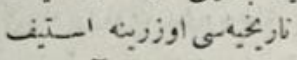

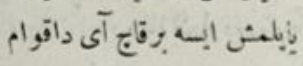
.

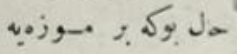

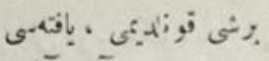

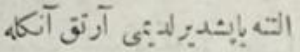

$$
\text { ك }
$$

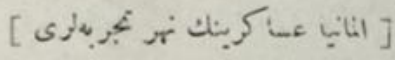

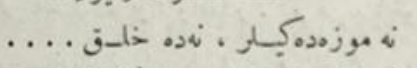

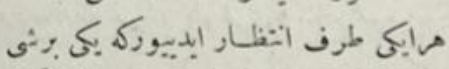

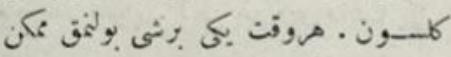

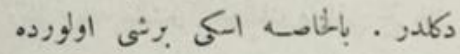

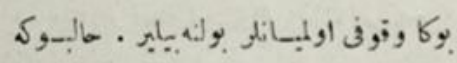

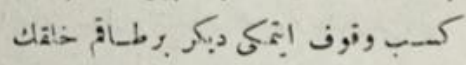

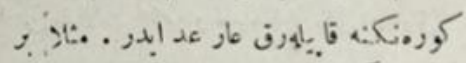

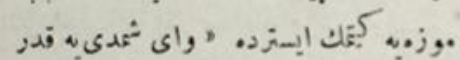

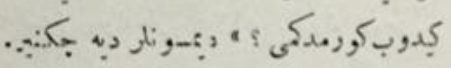

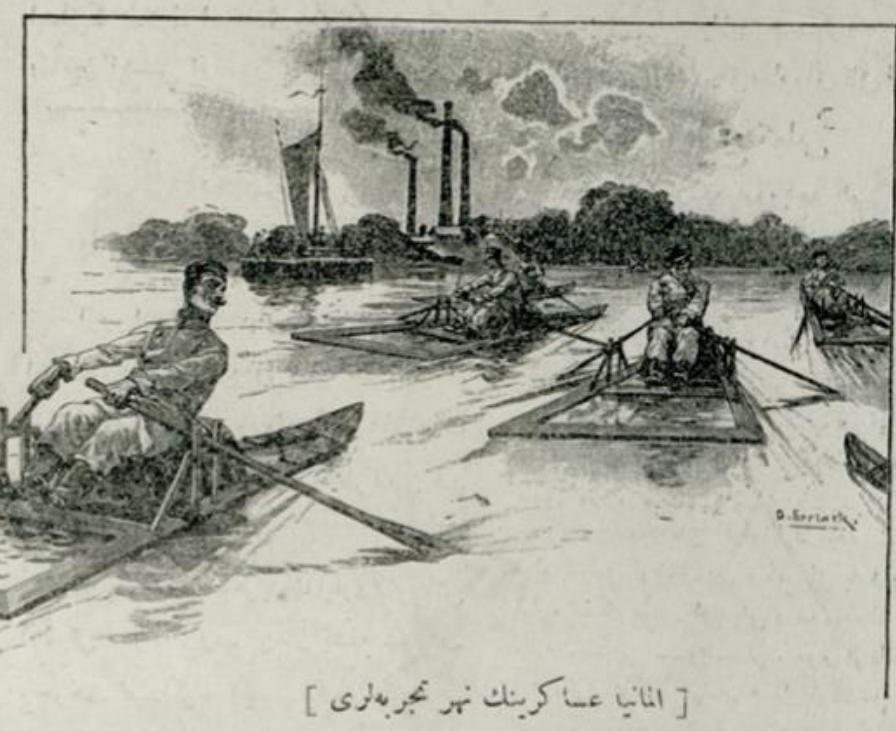

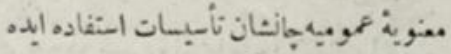

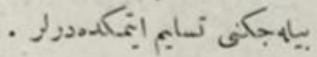

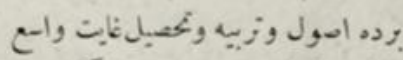

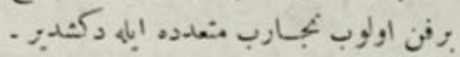

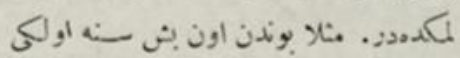

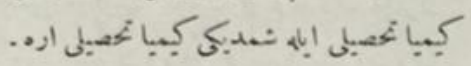

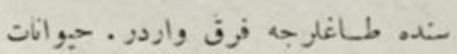

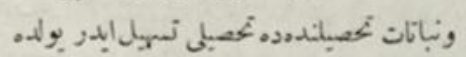

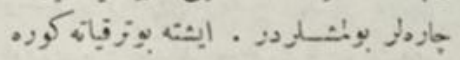

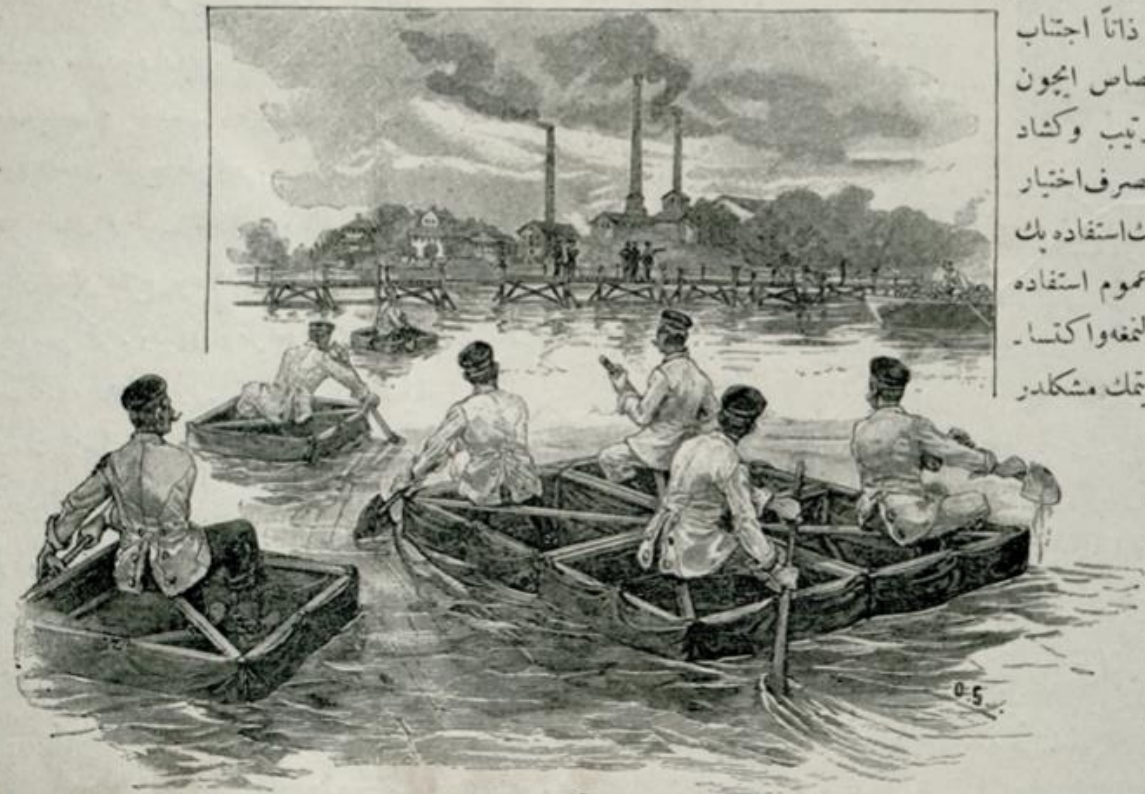

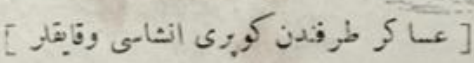

إيساخو

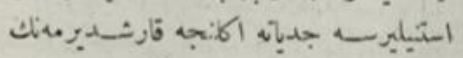

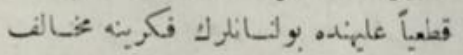

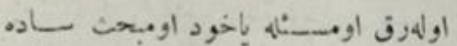

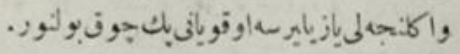

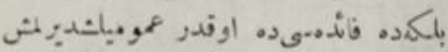
جديات ارباب اختصاص ائون لازمدر.

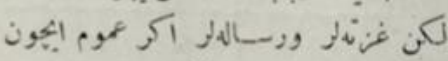

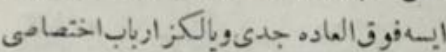

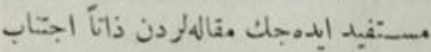

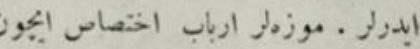

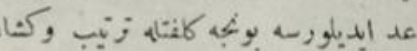

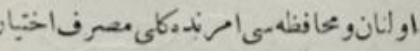

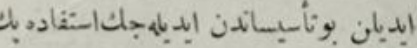

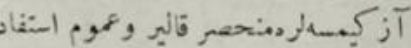

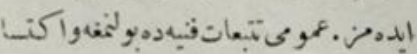

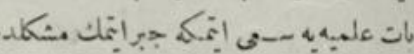

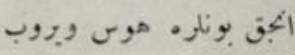

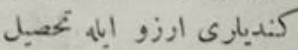

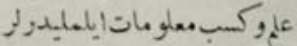

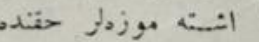

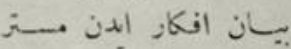

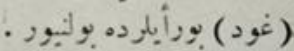

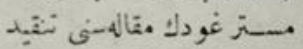
الدنا

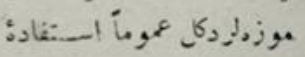




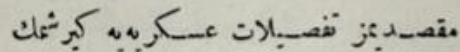

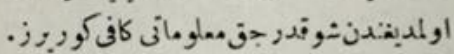

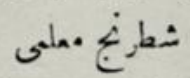

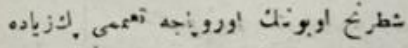

اونا

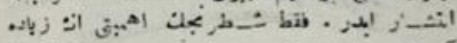

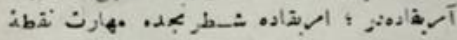

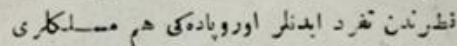

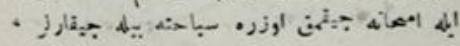

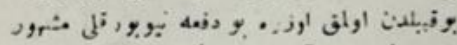

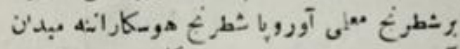

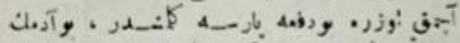

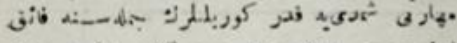

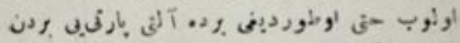

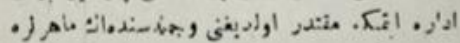

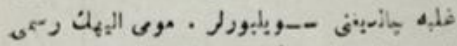

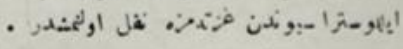

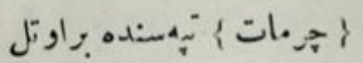

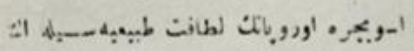

•.

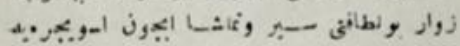

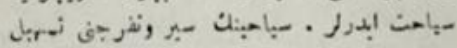

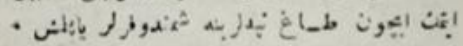

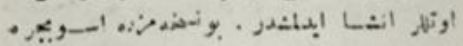

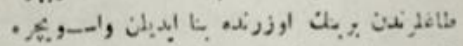

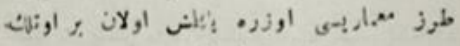

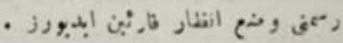

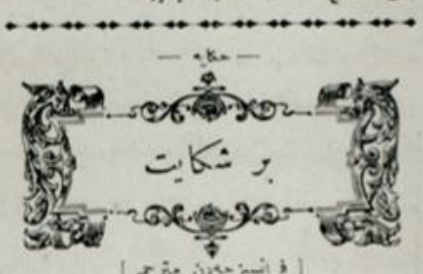

$$
\text { 3, : :'יورد دوبانوبل }
$$

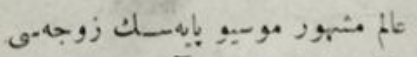

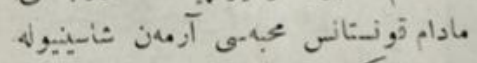

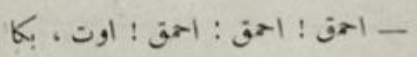

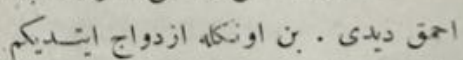

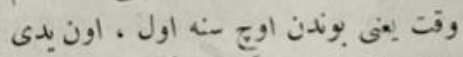

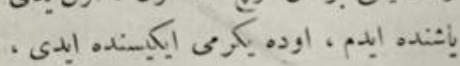

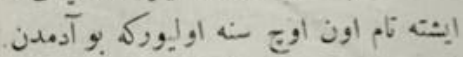

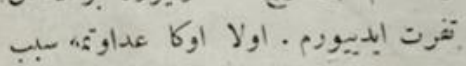

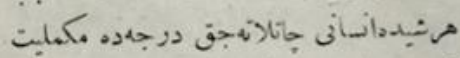

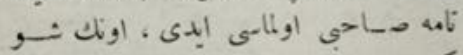

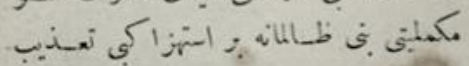

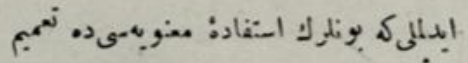

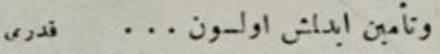

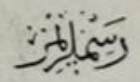

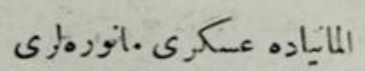

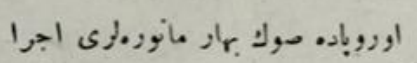

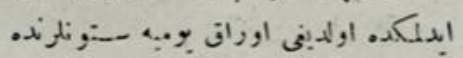

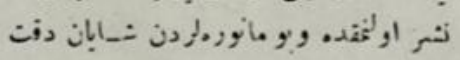

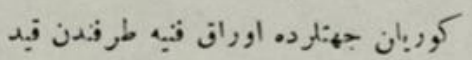
- 1

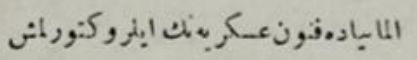

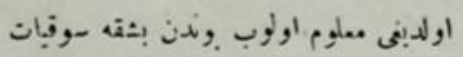

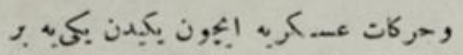

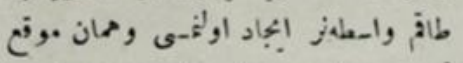

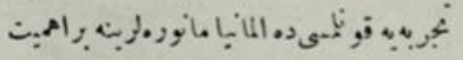

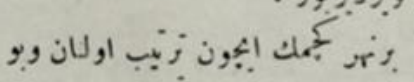

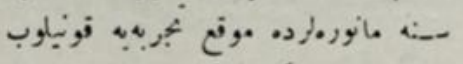

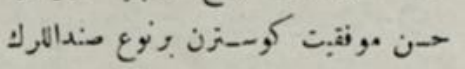

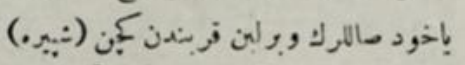

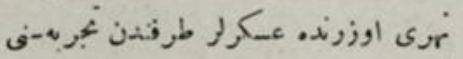

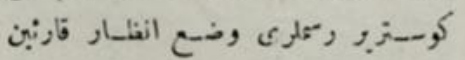

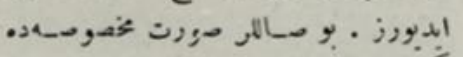

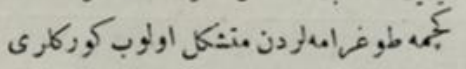

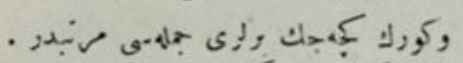

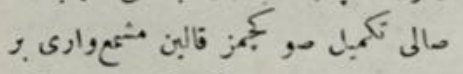

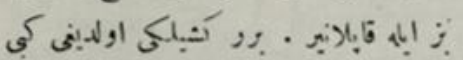

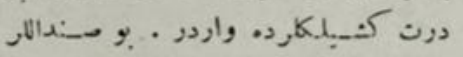

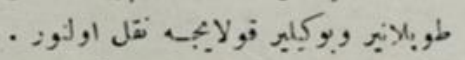

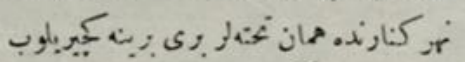

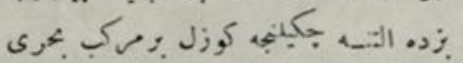

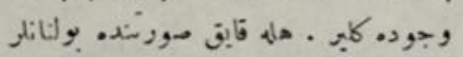

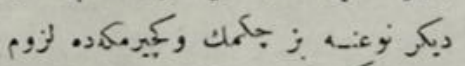

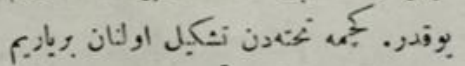

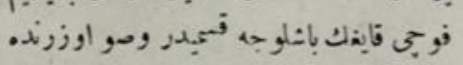

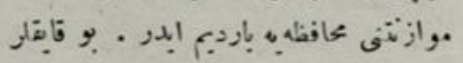

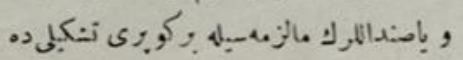

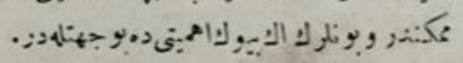

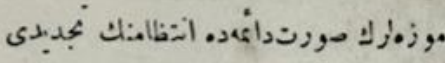

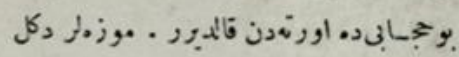

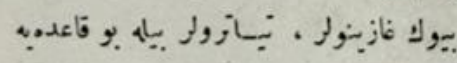

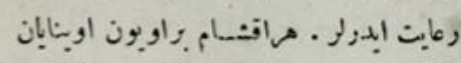

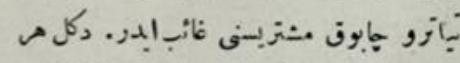

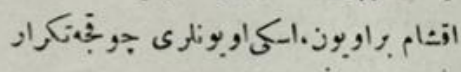

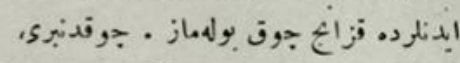

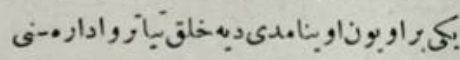

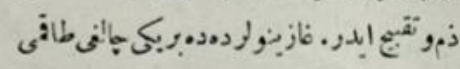

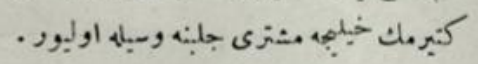

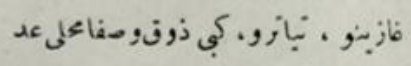

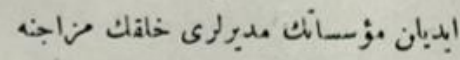

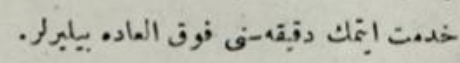

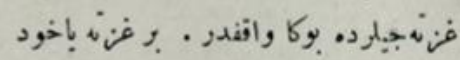

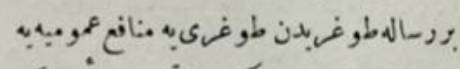

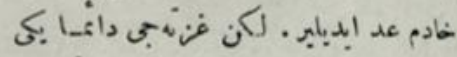

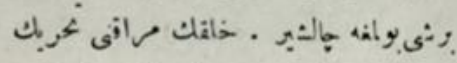

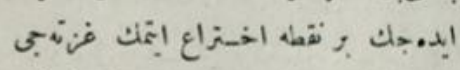

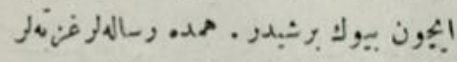

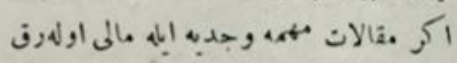

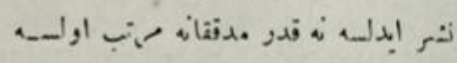

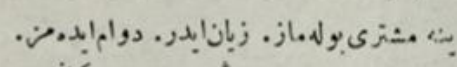

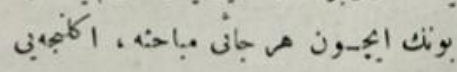

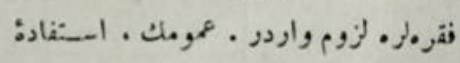

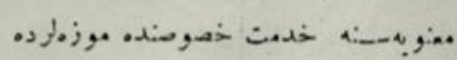
وقاعدمدن خلارج طوتماز .

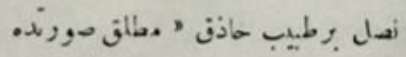

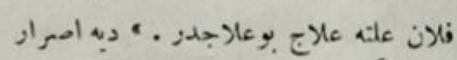

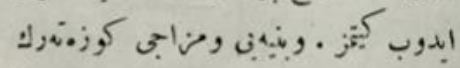

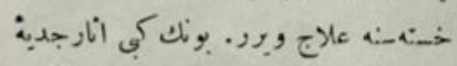

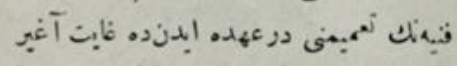

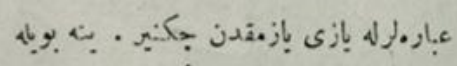

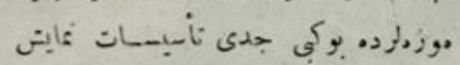

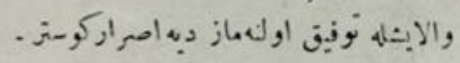

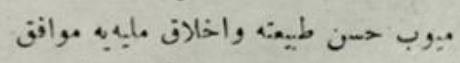

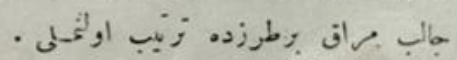

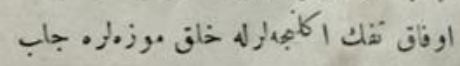

